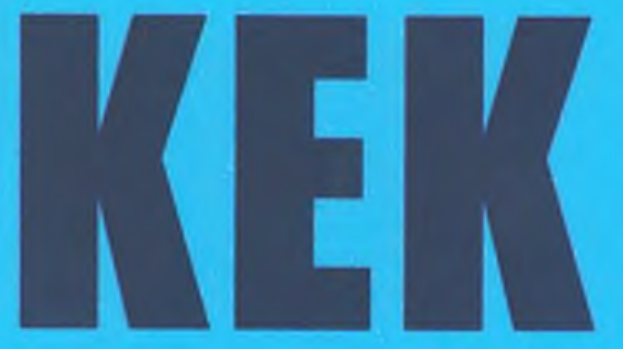

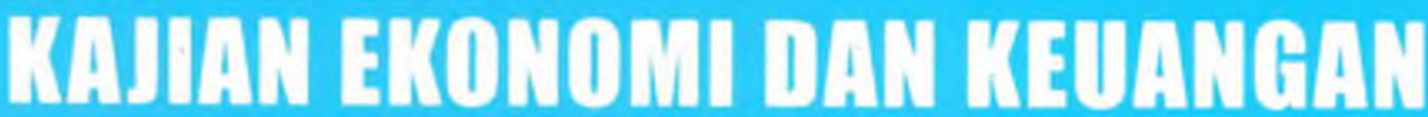

- Analisis Urgensitas Pinjaman Luar Negeri Indonesia Dalam Rangka Pembiayaan Defisit APBN

- Phasing Out Kerosene Subsidy in Developing Countries. Case Study of India and Indonesia

- Kontribusi, Efektivitas, Efisiensi, dan Faktorfaktor yang Mempengaruhi Penerimaan Pajak Pertambahan Nilai

- Studi Potensi Pendanaan Climange Change Pada Lembaga Keuangan Multilateral

- Tax Harmonization ASEAN Melalui ASEAN Tax Forum : Pembelajaran Dari Proses Tax Harmonization Eropa

\begin{tabular}{|c|c|c|c|c|c|}
\hline Kaj. Eko. Keu. & Vol. 16 & No.1 & Jaharta 2011 & $\begin{array}{c}\text { ISSN 1410- } \\
3249\end{array}$ & $\begin{array}{c}\text { Terakreditasi } 8 \\
\text { (No. Akreditasi: } \\
\text { 30B/AU2/P2MBU08/2010) }\end{array}$ \\
\hline
\end{tabular}

Pusat Kebijakan Ekonomi Makro

Badan Kebijakan Fiskal

Kementerian Keuangan

Republlk Indonesia 


\section{K A J I A N}

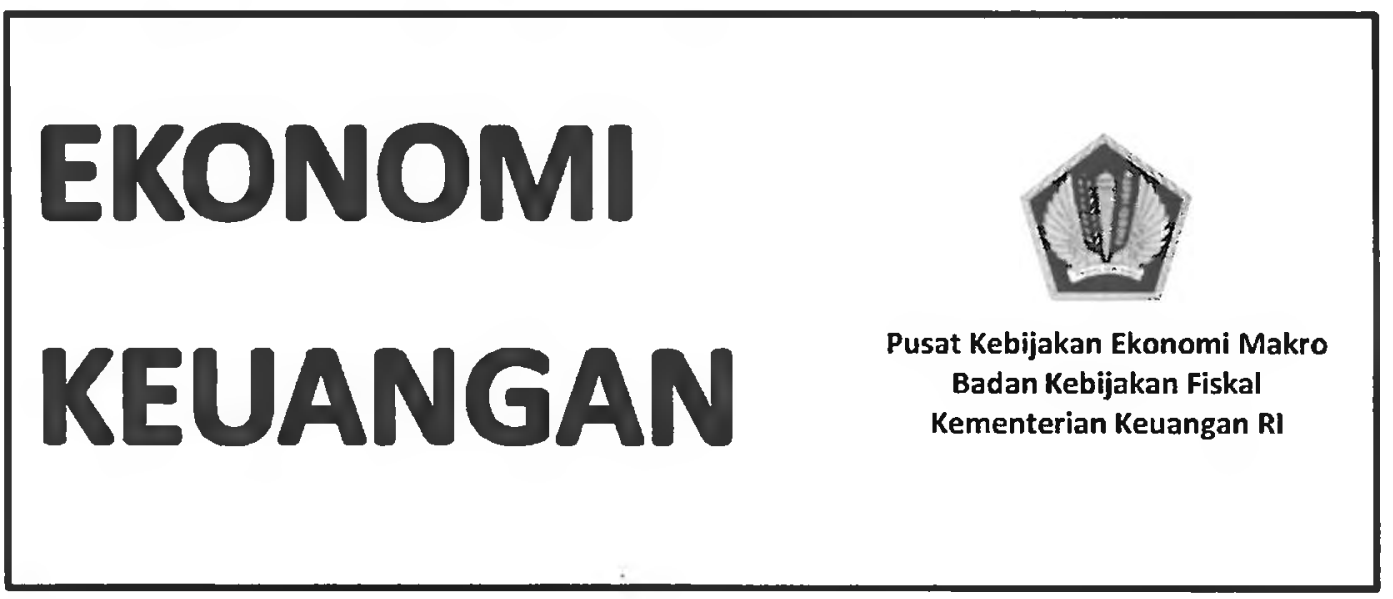

Analisis Urgensitas Pinjaman Luar Negeri Indonesia Dalam

Rangka Pembiayaan Defisit APBN

Phasing Out Kerosene Subsidy in Developing Countries. Case

Study of India and Indonesia

Kontribusi, Efektivitas, Efisiensi dan Faktor-faktor yang

Mempengaruhi Pajak Pertambahan Nilai

Studi Potensi Pendanaan Climate Change Pada Lembaga Keuangan Multilateral

Tax Harmonization ASEAN Melalui ASEAN Tax Forum : Pembelajaran

Dari Proses Tax Harmonization Eropa

\begin{tabular}{|l|l|l|l|l|}
\hline Kaj. Eko. \& Keu. & Vol. 15 & No.1 & Jakarta 2011 & ISSN 1410-3249 \\
\hline
\end{tabular}




\section{KATA SAMBUTAN}

Kami panjatkan rasa syukur kepada Tuhan Yang Maha Esa atas terbitnya Kajian Ekonomi dan Keuangan edisi ini ke hadapan pembaca sekalian. Pada edisi ini, kami menyajikan berbagai topik yang berkaitan dengan analisis dan dampak kebijakan publik di bidang ekonomi dan keuangan negara.

Kajian pada volume kali ini diisi oleh berbagai topik tulisan yaitu Analisis Urgensitas Pinjaman Luar Negeri Indonesia Dalam Rangka Pembiayaan Defisit APBN; Phasing Out Kerosene Subsidy in Developing Countries. Case Study of India and Indonesia; Kontribusi, Efektivitas, Efisiensi, dan Faktor-faktor yang Mempengaruhi Penerimaan Pajak Pertambahan. Nilai; Studi Potensi Pendanaan Climange Change Pada Lembaga Keuangan Multilateral; dan Tax Harmonization ASEAN Melalui ASEAN Tax Forum : Pembelajaran Dari Proses Tax Harmonization Eropa. Adapun para penulis yang berkontribusi pada penerbitan kali ini yaitu Abdul Aziz, Mahpud Sujai, M. Syarif Mulyadi, R. Nurhidajat, Sigit Setiawan, Suska dan Yuventus Effendi.

Demikianlah kata pengantar yang dapat kami sampaikan. Ibarat peribahasa tiada gading yang tak retak, maka kami menyadari kajian ini tentunya masih terdapat kekurangan baik yang disengaja maupun yang tidak kami sengaja. Oleh karena itu, kami mengharapkan masukan dari para pembaca guna perbaikan di masa yang akan datang. Selanjutnya, kami berharap jurnal ini dapat memberikan manfaat kepada para pembaca sekalian. Selamat membaca!

Jakarta, 2011

Dewan Redaksi 


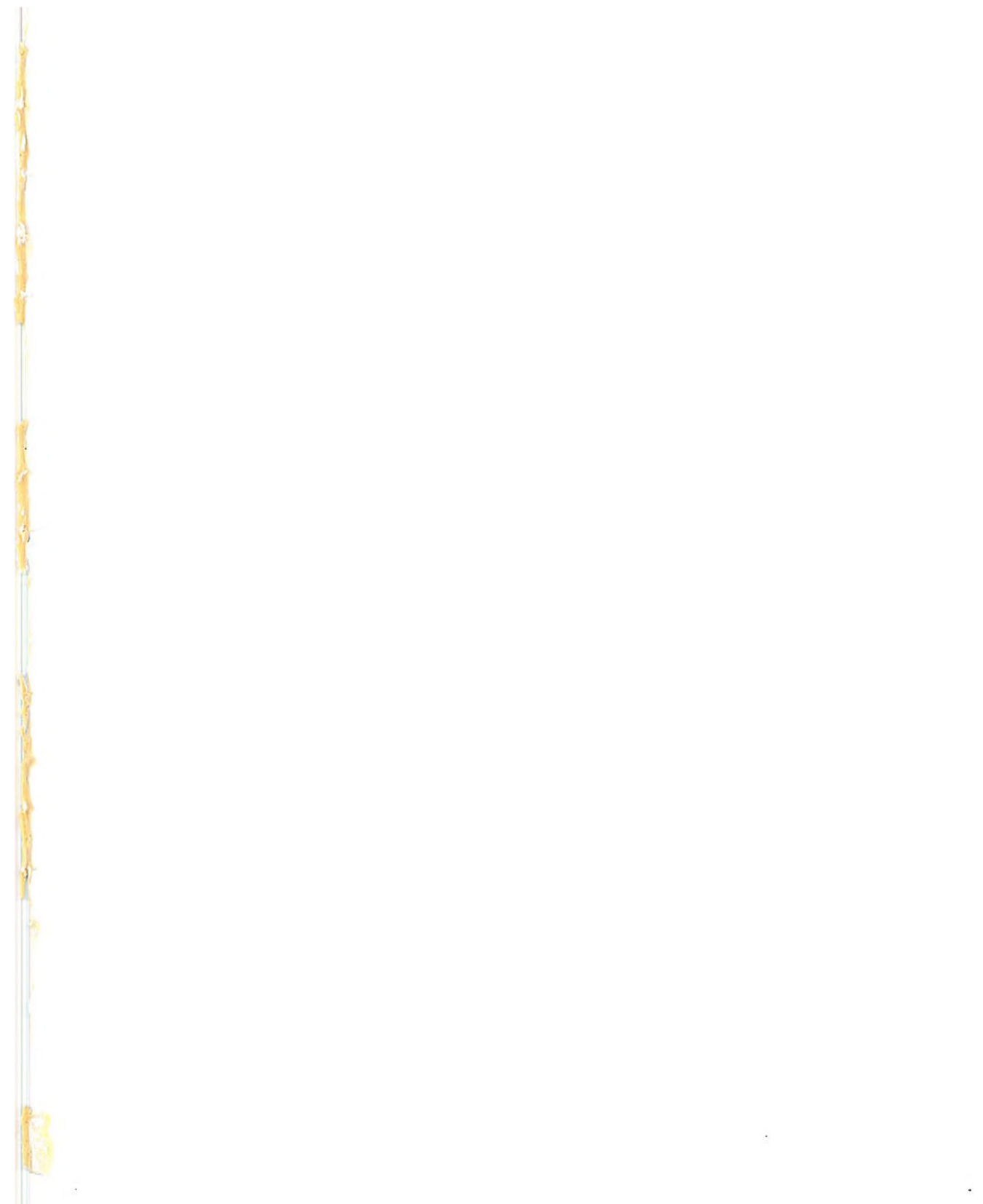




\section{DAFTAR ISI}

\section{Cover}

Dewan Redaksi ................................................................................................................. ii

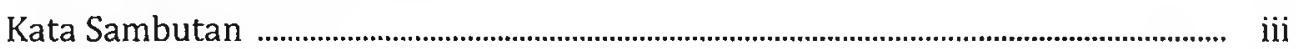

Daftar Isi ............................................................................................................................. $\quad \mathrm{v}$

Daftar Tabel ................................................................................................................. vi

Daftar Gambar .................................................................................................................. vii

Kumpulan Abstraksi ................................................................................................................ ix

ANALISIS URGENSITAS PINJAMAN LUAR NEGERI INDONESIA DALAM RANGKA PEMBIAYAAN DEFISIT APBN

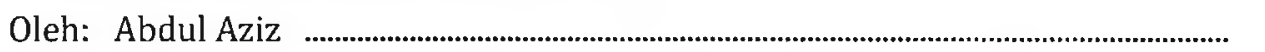

PHASING OUT KEROSENE SUBSIDY IN DEVELOPING COUNTRIES.

CASE STUDY OF INDIA AND INDONESIA

Oleh: Mahpud Sujai

KONTRIBUSI, EFEKTIVITAS, EFISIENSI, DAN FAKTOR-FAKTOR YANG MEMPENGARUHI PENERIMAAN PAJAK PERTAMBAHAN NILAI

Oleh: M. Syarif Mulyadi

Studi Potensi Pendanaan Climange Change Pada Lembaga

Keuangan Multilateral

Oleh: R. Nurhidajat dan Sigit Setiawan

Tax Harmonization ASEAN Melalui ASEAN Tax Forum :

Pembelajaran Dari Proses Tax Harmonization Eropa

Oleh: Suska dan Yuventus Effendi 87 


\section{DAFTAR TABEL}

\section{ANALISIS URGENSITAS PINJAMAN LUAR NEGERI INDONESIA DALAM RANGKA PEMBIAYAAN DEFISIT APBN}

Tabel 2.1. Ringkasan APBN 2001-2009

Tabel 2.2. Perkembangan Penerimaan Negara Pada APBN 2001 s.d. APBN 2009

Tabel 2.3. Perkembangan Belanja Negara Pada APBN 2001 s.d. APBN 2009 .. 7

Tabel 3.1. Penarikan Pinjaman Luar Negeri dan Defisit Anggaran ....................... 12

Tabel 3.2. Penarikan dan Pembiayaan PLN Negara Indonesia Tahun Anggaran 2002 s.d. 2009

Tabel 3.3. Rasio Pembayaran PLN Terhadap Penarikan PLN ................................... 14

Tabel 3.4. Model Dugaan Pinjaman Luar Negeri Indonesia ...................................... 15

Tabel 3.5. White Heteroske da Sticity Test ....................................................................... 16

Tabel 3.6. Correlation Matrix ...................................................................................... 16

Tabel 3.7. Breusch-Godfrey Serial Correlation LM Test .......................................... 17

Tabel 3.8. Pembiayaan Non Utang 2010 dan 2011 .................................................. 25

Tabel 3.9. Perkembangan Pinjaman Pemerintah Negara Indonesia Tahun 1998 dan 2009

PHASING OUT KEROSENE SUBSIDY IN DEVELOPING COUNTRIES.

\section{CASE STUDY OF INDIA AND INDONESIA}

Table 3.1. Fuel Subsidy in India

\section{STUDI POTENSI PENDANAAN CLIMANGE CHANGE PADA LEMBAGA}

\section{KEUANGAN MULTILATERAL}

Tabel 5.1. Distribusi Proyek CDM di Asia Tenggara

\section{TAX HARMONIZATION ASEAN MELALUI ASEAN TAX FORUM :}

\section{PEMBELAJARAN DARI PROSES TAX HARMONIZATION EROPA}

Tabel 2.1. Perkembangan Harmonisasi Pajak Uni Eropa .......................................... 94

Tabel 3.1. Tarif Pajak Tidak Langsung Negara ASEAN ................................................ 95

Tabel 3.2. Tarif Pajak Penghasilan Badan Negara ASEAN ........................................ 96

Tabel 3.3. Daftar Tax Treaty Indonesia dengan Negara ASEAN ............................. 96

Tabel 3.4. Daftar Tax Treaty Antar Negara ASEAN ...................................................... 97

Tabel 3.5. Intra- and Extra-ASEAN Trade, 2009 ........................................................ 98

Tabel 3.6. Rasio Penerimaan Pajak terhada PDB dari Negara Anggota ASEAN Periode 1996-2009 .......................................................................... 99

Tabel 3.7. Tarif Pajak Tidak Langsung Negara Uni Eropa 2004-2009 .................. 100

Tabel 3.8. Tarif Pajak Langsung Negara Uni Eropa1999-2009 ............................... 101 


\section{DAFTAR GAMBAR}

\section{ANALISIS URGENSITAS PINJAMAN LUAR NEGERI INDONESIA DALAM RANGKA PEMBIAYAAN DEFISIT APBN}

Grafik 3.1. Komposisi SUN Tidak Ideal ................................................................. 27

Grafik 3.2. Komposisi SUN Ideal ......................................................................... 27

\section{PHASING OUT KEROSENE SUBSIDY IN DEVELOPING COUNTRIES. CASE STUDY OF INDIA AND INDONESIA}

Picture 3.1. Fuel Subsidy Formula ………………................................................................. 39

Picture 3.2. Kerosene to LPG Conversion Road Map .................................................. 41

Picture 3.3. Consumption Volume of Kerosene and LPG ......................................... 43

Picture 3.4. The Amount of Subsidized Kerosene and LPG ..................................... 43

Picture 3.5. Proportion of Kerosene to LPG Usage ................................................... 44

Picture 3.6. Estimated Amount of Subsidy Diversion in India ................................ 46

KONTRIBUSI, EFEKTIVITAS, EFISIENSI, DAN FAKTOR-FAKTOR YANG MEMPENGARUHI PENERIMAAN PAJAK PERTAMBAHAN NILAI

Grafik 3.1. Tax Ratio (dalam persen) ......................................................................... 60

Grafik 3.2. Perkembangan PDB, Konsumsi Nasional dan Penerimaan PPN (dalam miliar Rp) 61

Grafik 3.3. Peran PPN dan PPh Terhadap Total Penerimaan Perpajakan (dalam persen) 62

Grafik 3.4. Kontribusi Penerimaan PPN dan PPh Dalam Membiayai Belanja Pemerintah(dalam persen) ............................................................. 64

Grafik 3.5. Perkembangan Penerimaan Pajak (dalam miliar rupiah) ................... 65

Grafik 3.6. Kinerja Penerimaan PPN ................................................................................ 66

Grafik 3.7. Potensi dan Realisasi PPN (dalam triliun RP) ......................................... 67

Grafik 3.8. Gap Antara Potensi dan Realisasi PPN (dalam triliun RP) ................. 67

STUDI POTENSI PENDANAAN CLIMANGE CHANGE PADA LEMBAGA KEUANGAN MULTILATERAL

Gambar 3.1 Diagram Mekanisme Kerja CDM

Gambar 6.1 Mobilisasi Pembiayaan Dengan Mekanisme Pasar ................................... 81

TAX HARMONIZATION ASEAN MELALUI ASEAN TAX FORUM : PEMBELAJARAN DARI PROSES TAX HARMONIZATION EROPA 


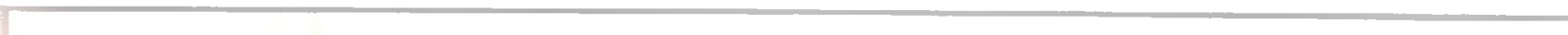




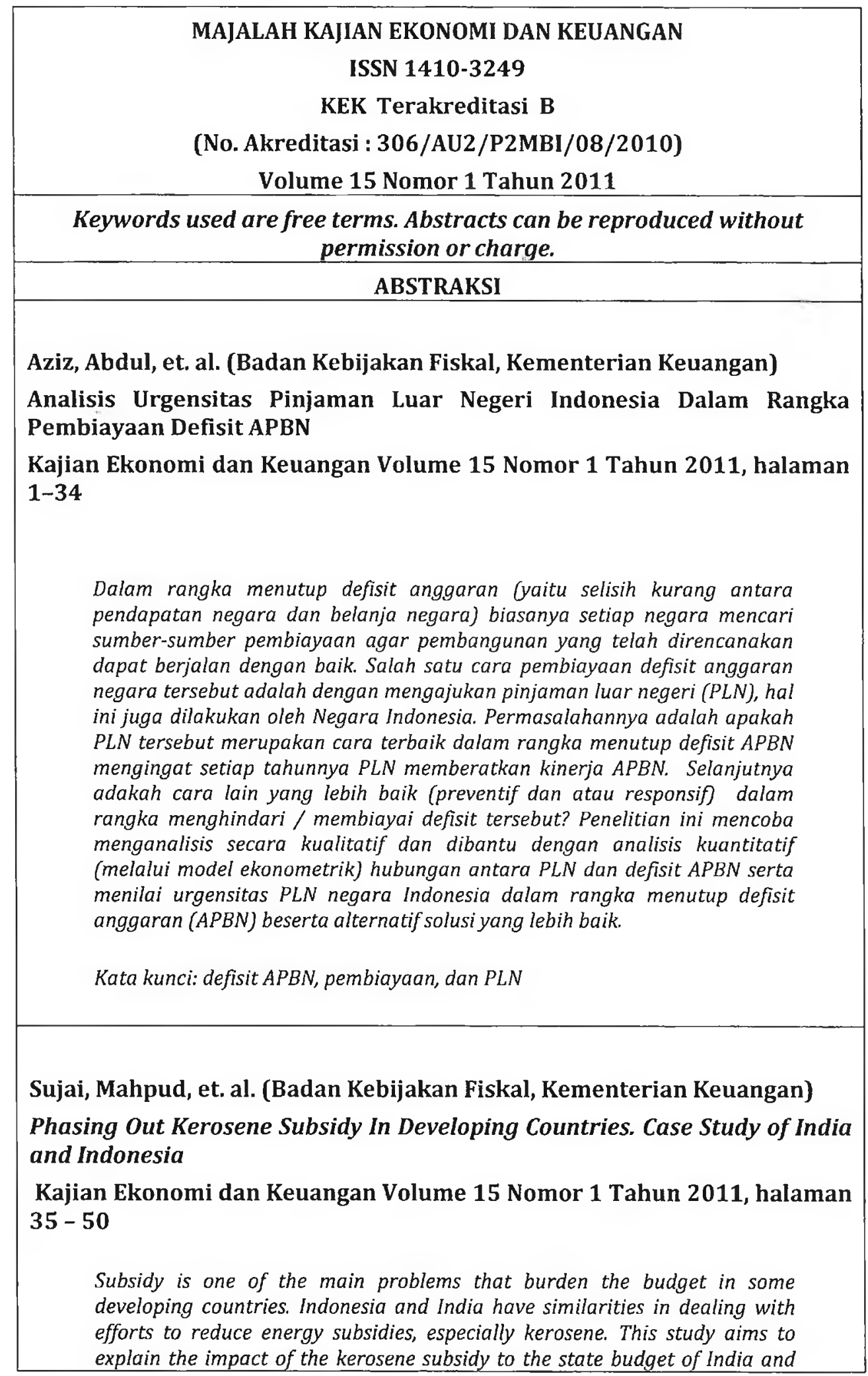




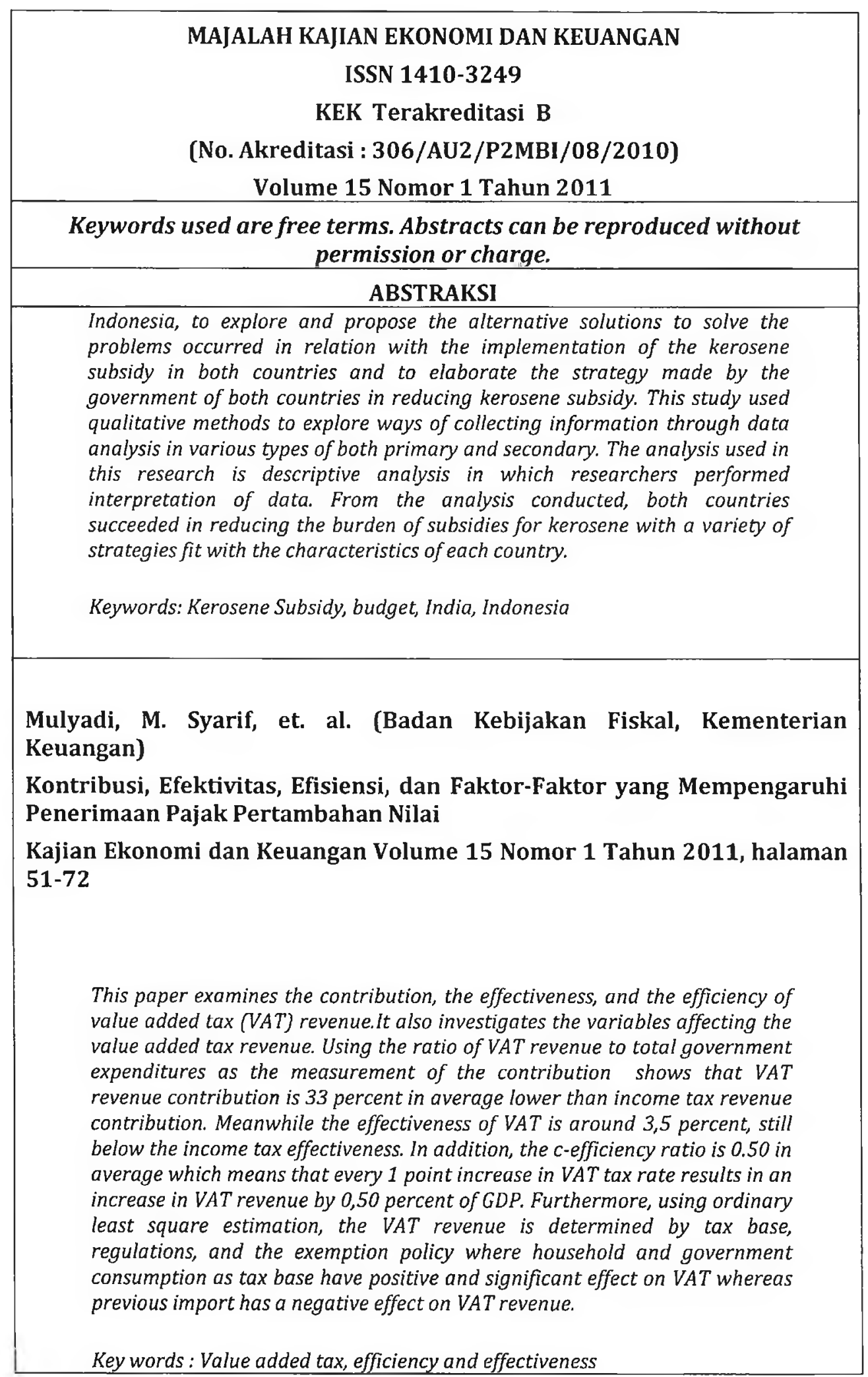




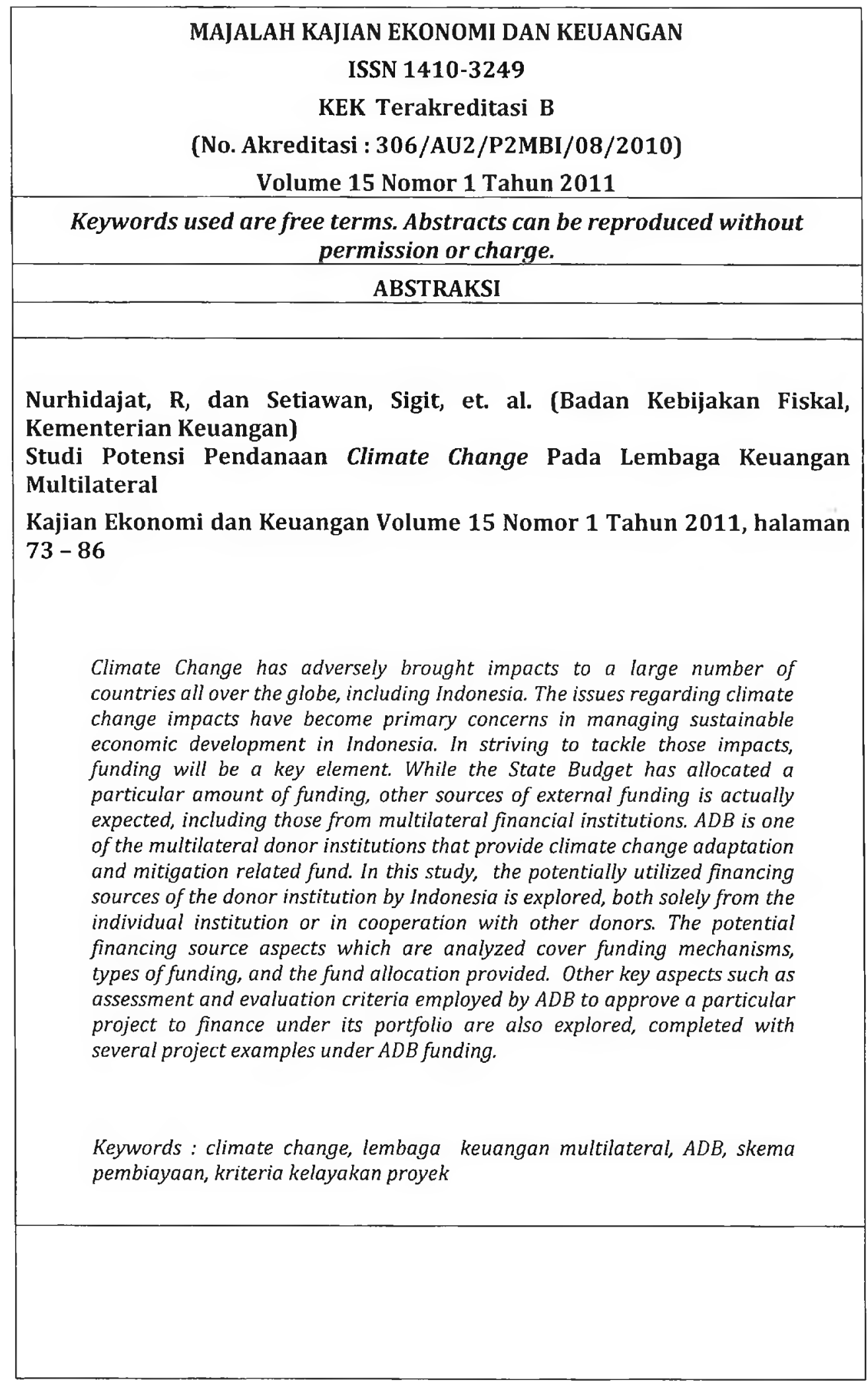




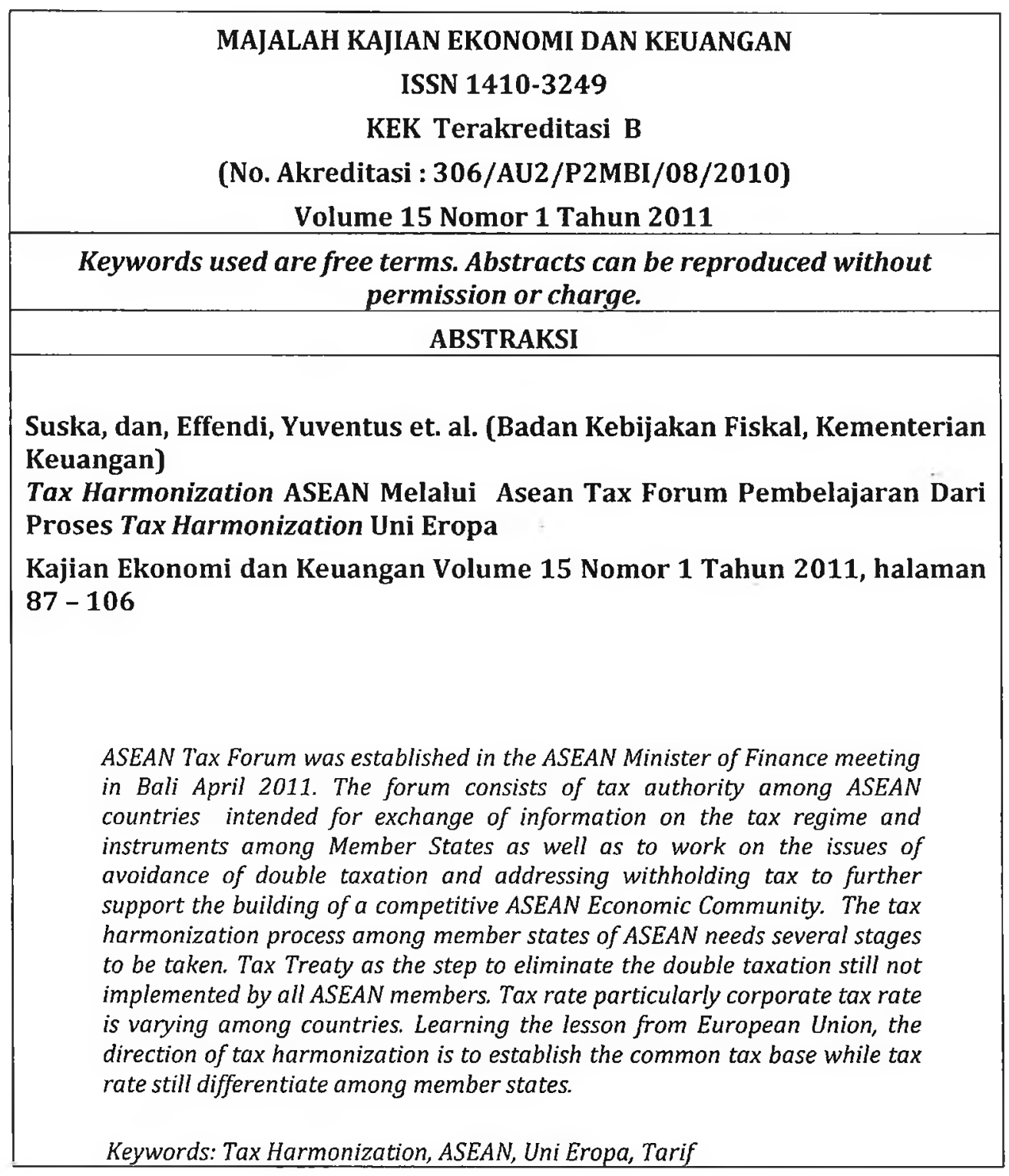




\title{
TAX HARMONIZATION ASEAN MELALUI ASEAN TAX FORUM -PEMBELAJARAN DARI PROSES TAX HARMONIZATION UNI EROPA-
}

Oleh:

Suska dan Yuventus Effendi ${ }^{1}$

\begin{abstract}
ASEAN Tax Forum was established in the ASEAN Minister of Finance meeting in Bali April 2011. The forum consists of tax authority among ASEAN countries intended for exchange of information on the tax regime and instruments among Member States as well as to work on the issues of avoidance of double taxation and addressing withholding tax to further support the building of a competitive ASEAN Economic Community. The tax harmonization process among member states of ASEAN needs several stages to be taken. Tax Treaty as the step to eliminate the double taxation still not implemented by all ASEAN members. Tax rate particularly corporate tax rate is varying among countries. Learning the lesson from European Union, the direction of tax harmonization is to establish the common tax base while tax rate still differentiate among member states.
\end{abstract}

Keywords: Tax Harmonization, ASEAN, Uni Eropa, Tarif

\section{PENDAHULUAN}

\subsection{Latar Belakang}

Pembentukan ASEAN Tax Forum merupakan salah satu hasil pertemuan Menteri Keuangan ASEAN yang berlangsung di Bali pada bulan April 2011. ASEAN Tax Forum merupakan inisiatif untuk memperkuat kerjasama dalam bidang perpajakan. Melalui forum ini diharapkan dilakukan pertukaran informasi antar negara ASEAN mengenai ketentuan perpajakan serta menghindari terjadinya pajak berganda dan menangani witholding tax untuk membangun komunitas ASEAN yang lebih kompetitif.

ASEAN Tax Forum juga menjadi bagian dari persiapan pembentukan Komunitas Ekonomi ASEAN. Komunitas Ekonomi ASEAN sendiri bertujuan untuk menciptakan kawasan yang stabil, sejahtera, dan sangat kompetitif, di mana

I Calon Fungsional Peneliti Pada Pusat Kebijakan Ekonomi Makro, Badan Kebijakan Fiskal, Kementerian Keuangan 
terdapat kebebasan lalu lintas barang, jasa, investasi, modal, pembangunan ekonomi yang setara, dan pengurangan kemiskinan dan kesenjangan sosial ekonomi dengan membentuk pasar tunggal dan basis produksi pada 2015. Dengan sistem perpajakan yang selaras antar negara ASEAN, maka ASEAN sebagai suatu komunitas ekonomi dapat menjadi kawasan yang mampu bersaing dengan kawasan ekonomi yang lain.

Indonesia sendiri dalam pertemuan Menteri Keuangan di Bali menyampaikan Pemerintah Indonesia meminta negara-negara di ASEAN tidak lakukan perang insentif pajak, guna menarik dana dari investor luar negeri karena mengancam kondisi keuangan negara (detikfinance, 6 April 2011).

Lalu bagaimanakah sebenarnya kebijakan perpajakan yang berlaku di negara ASEAN saat ini dan keselarasan antar kebijakan pajak antar negara ASEAN. Bagaimana peran yang dapat dijalankan ASEAN Tax Forum untuk mencapai tujuan menjadikan kawasan ASEAN sebagai komunitas yang kompetitif.

\subsection{Tujuan Penelitian}

1. Mengetahui kondisi keselarasan kebijakan perpajakan di antara negara ASEAN saat ini dan menjelaskan model tax harmonization yang dilakukan Uni Eropa.

2. Memberikan saran untuk pelaksanaan ASEAN tax Forum dalam rangka mencapai tujuan komunitas ekonomi ASEAN yang lebih kompetitif.

\subsection{Metodologi}

Metodologi yang digunakan dalam penelitian ini adalah deskriptif yaitu dengan memberikan gambaran kondisi penyelarasan pajak di antara negara ASEAN saat ini dan membandingkan nya dengan teori tax harmonization untuk memberi gambaran sejauh mana tax harmonization yang telah dilakukan di kalangan negara ASEAN. Kemudian dilakukan perbandingan dengan model tax harmonization yang sedang dilakukan oleh European Union.

Pengumpulan data dilakukan dengan perolehan data sekunder dari beberapa sumber yaitu website organisasi ASEAN, hasil survei tarif pajak beberapa negara yang diadakan oleh KPMG dan sumber-sumber relevan lainnya.

Ruang lingkup penelitian terutama berfokus kepada kondisi perpajakan negara-negara di ASEAN termasuk kondisi P3B, penerimaan pajak dibandingkan dengan GDP, tarif pajak langsung maupun tidak langsung, dan volume perdagangan. Perbandingan dengan European Union juga dimasukkan untuk memberikan gambaran sejauh mana langkah-langkah yang telah dilaksanakan oleh negaranegara ASEAN untuk mewujudkan pembentukan Komunitas Ekonomi ASEAN. 


\section{TINJAUAN PUSTAKA}

\subsection{Tax Harmonization}

Larkin (IBFD,2005) sebagaimana dikutip oleh Velayos (2007) mendefinisikan penyelerasan pajak atau tax harmonization sebagai penghapusan perbedaan atau inkonsistensi antara sistem pajak dari yurisdiksi yang berbeda, sehingga membuat perbedaan atau inkonsistensi menjadi sesuai satu sama lain. Terdapat dua bentuk Tax Harmonization (Edwards:2008,154) yaitu Direct Tax Harmonization dan Indirect Tax Harmonization. Dengan menerapkan harmonisasi tarif pajak langsung dan tidak langsung, maka Wajib Pajak tidak dapat memanfaatkan perbedaan tarif pajak antar negara.

Velayos (2007) kemudian menjabarkan proses dari tax harmonization ke dalam beberapa langkah dari yang tertinggi ke yang terendah sesuai dengan komitmen politik antar negara:

\section{Gambar 2.1.}

\section{Degree of Harmonization}

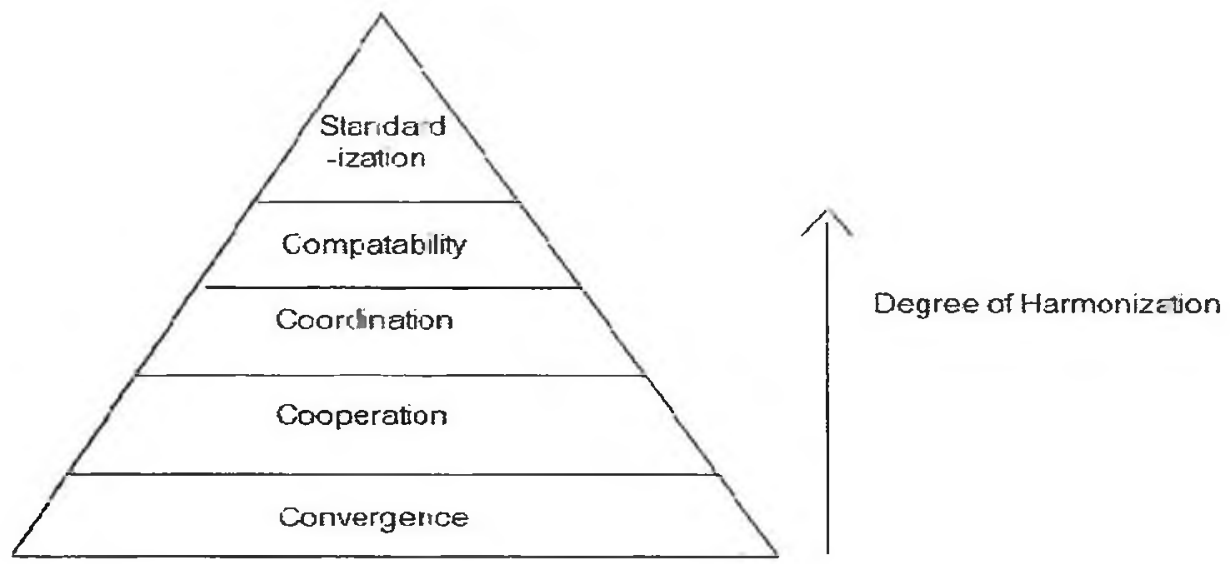

Sumber: Velayos, Fernando; Alberto Barreix; \& Luiz Villela. 2007. Regional Integration and Tax Harmonization: Issues and Recent Experiences

Cano (1996) dalam Velayos (2007) mendefinisikan masing-masing tahap tax harmonization sebagai berikut:

\section{Standardization}

Standardization merupakan tingkat tertinggi tax harmonization. Dapat didefinisikan sebagai memiliki pajak yang sama atau " menyamakan beban pajak yang dikenakan pada item yang sama atau keadaan yang sama".. Contohnya adalah penerapan tarif eksternal umum (CET). 


\section{Compatibility}

"menyesuaikan struktur pajak untuk mengatasi atau mengimbangi efek distorsi yang disebabkan oleh perbedaan beban pajak dalam proses integrasi ekonomi".

Menyesuaikan unsur-unsur dalam struktur pajak tidak berarti bahwa semua unsur harus selalu identik. Bahkan, compatibility tidak mempengaruhi tingkat pajak atau manfaat pajak, setidaknya tidak sepenuhnya sama. Alasannya adalah bahwa jika ini terjadi, akan ada hampir tidak ada perbedaan antara compatibility dan standardization. Unsur yang sangat sensitif seperti tingkat pajak pada kategori ini memberikan lebih banyak ruang bagi para pembuat kebijakan untuk membuat keputusan kebijakan pajak.

\section{Coordination}

Didefinisikan sebagai kategori "in between" yaitu segala keadaan yang tidak cocok dengan salah satu dari empat kategori lain. Adapun dalam hal tingkat komitmen politik yang terlibat dalam kategori ini, merupakan langkah maju relatif terhadap dua kategori berikut,

\section{Cooperation}

Merupakan pemberian asistensi secara timbal balik, baik untuk alasan timbal-balik (misalnya, satu negara memberi pasokan informasi pajak dengan harapan bahwa ia akan menerima informasi dari negara rekanannya di lain waktu) atau demi kepentingan bersama (seperti ketika pajak ganda terdeteksi dan dua negara melakukan perjanjian untuk bekerja sama). Perbedaan juga bisa ditarik antara kerjasama praktis (seperti dalam contoh sebelumnya) dan kerjasama teoretis (misalnya, memberikan bantuan atau berbagi pengalaman praktek terbaik di bidang perpajakan). Dalam kasus apapun, cooperation tidak berarti memiliki kebijakan pajak yang sama. Dimungkinkan terjadinya mekanisme kerjasama bilateral dan multilateral, dengan menciptakan administrasi pajak lebih homogen, berkontribusi untuk aplikasi yang lebih konsisten dari sistem pajak, sehingga memastikan kesetaraan horisontal yang lebih besar dan mensejajarkan kesempatan bagi pelaku ekonomi. Selain itu, penciptaan mekanisme kerjasama membuat negara sadar dan mengadopsi solusi terbaik, baik dari segi administrasi pajak dan kebijakan-misalnya, setelah konsultasi memutuskan untuk mengadopsi, kriteria penafsiran yang sama dalam kasus yang kompleks ketika undang-undang serupa atau ada perjanjian penghindaran pajak berganda

\section{Convergence}

Merupakan tindakan spontan (kadang-kadang tak terelakkan, meskipun tidak diinginkan) sebagai suatu solusi terhadap permasalahan yang sama antar negara yang terlibat, sebagai akibat dari globalisasi dan persaingan. Konvergensi 
diklasifikasikan pada langkah kelima dan terakhir dari sudut pandang komitmen politik sukarela karena tidak ada tindakan harmonisasi tertentu telah diambil untuk dengan kemauan politik, tetapi karena negara ini tidak bisa lepas dari tren atau mengakui (mungkin secara tidak sadar atau bertentangan dengan keinginan sendiri ) bahwa ini adalah pendekatan terbaik yang harus diambil. Karena konvergensi ini bersifat spontan, selalu ada unsur ketidaknyamanan atau, setidaknya negara yang terlibat bersikap pasif.

\subsection{Tax Competition}

\subsubsection{Definisi Tax Competition}

Winner (2005) mendefinisikan tax competition sebagai suatu aktifitas fiskal di wilayah tertentu yang menyebabkan eksternalitas fiskal bagi wilayah yuridiksi yang lain.

\subsubsection{Penelitian terdahulu}

Tohari \& Retnawati (2010) melakukan penelitian Tax Competition terhadap 5 negara ASEAN menggunakan variabel effective marginal tax rate (EMTR) dan effective average tax rate (EATR). EMTR adalah tarif pajak efektif yang dikenakan terhadap tambahan proyek investasi (nilai sekarang dari akumulasi arus kas yang dihasilkan dari setiap tambahan rupiah dari investasi). EMTR yang lebih tinggi menunjukkan tingginya cost of capital dan menurunkan arus modal yang masuk ke suatu negara. EATR adalah tarif pajak efektif yang dikenakan terhadap hasil yang didapatkan dari proyek investasi. EATR dihitung sebagai perbedaan proporsional antara pre dan post-tax yang dikenakan terhadap profit.

Hasil dari penelitian ini menyimpulkan bahwa tidak ada bukti terdapat tax competition di 5 negara ASEAN tersebut, kecuali untuk Malaysia dan Singapura yang menunjukkan kebijakan pajak bersifat investment-friendly sehingga cenderung menurunkan tarif pajaknya.

Berlianto (2009) dalam studinya mengenai Tax Competition dan Tax Harmonization negara ASEAN menyimpulkan bahwa hasil penelitian terhadap tax competition menunjukkan hasil yang beragam. Dalam hal tarif pajak, tidak terlihat terjadinya kompetisi karena penurunan tarif yang dilakukan negara-negara ASEAN relatif kecil kecuali Singapura menunjukkan kecenderungan menurunkan tarif pajaknya untuk menarik investasi, langkah ini diikuti oleh Malaysia, walaupun dampaknya terhadap kawasan ASEAN belum terlihat.Dalam hal tax harmonization, Berlianto (2009) menyimpulkan sulitnya menentukan level tax harmonization di ASEAN karena perbedaaan struktur pajak antar negara. Dalam hal tax treaty, terjadi keragaman antar negara dan tidak terdapat Tax Treaty yang komprehensif untuk seluruh negara ASEAN. 
Bettendorf et al (2009) dalam studi mengenai Corporate Tax Harmonization in the EU melakukan penelitian dengan menggunakan CGE terhadap harmonisasi PPh Badan di Uni Eropa dan hasilnya menunjukkan bahwa proposal harmonisasi PPh Badan baik dengan menggunakan common base maupun consolidation memberikan efek yang sama terhadap tax competition. Hal yang dapat dikatakan menguntungkan dari skema harmonisasi ini adalah berkurangnya compliance cost dari wajib pajak.

\subsection{Harmonisasi Pajak Model European Union (EU)}

Dalam tahap-tahap pembentukan EU, masalah perpajakan telah dijadikan pokok pembahasan. Perpajakan merupakan salah satu pokok yang dibahas dalam traktat Roma selain pergerakan barang, jasa, modal, dan lain-lain (Lessambo, 2010,19)

Salah satu cara untuk mengatasi aspek perpajakan dalam EU adalah dengan melakukan harmonisasi. Harmonisasi pajak digunakan untuk menggambarkan adanya ekualisasi tarif corporate tax dan standarisasi tax base di EU (Bond et al, 2000). Dalam prakteknya, harmonisasi pajak EU merupakan sebuah proses yang dimulai dengan traktat Roma yang sampai dengan saat ini belum selesai dilaksanakan.

Dalam proses harmonisasi, European Commission membagi pajak menjadi dua jenis yaitu pajak tidak langsung dan pajak langsung (Farrow \& Jogajaran, 2006).

PPN menjadi jenis pajak tidak langsung yang pertama kali diharmonisasi pada tahun 1977 dan diadaptasi pada tahun 1992 bersamaan dengan Bea Cukai. Walaupun PPN diatur dengan dengan menetapkan tarif standar PPN dan memiliki karakteristik yang mirip namun terdapat variasi untuk pajak tidak langsung terkait dengan produk beralkohol, BBM, dan tembakau.

Pajak langsung merupakan perdebatan sejak tahun 1962. Sampai dengan saat ini belum disepakati harmonisasi pajak langsung yang dapat memenuhi kriteria Velayos (2007), sehingga yang diterapkan pada saat ini adalah konvergensi pajak langsung (Farrow \& Jogajaran,2006).

Proposal terakhir yang sedang diajukan oleh European Commission adalah Common Consolidated Corporate Tax Base (CCCTB). CCCTB merupakan seperangkat peraturan yang mengatur mengenai cara penghitungan penghasilan bagi perusahaan-perusahaan yang beroperasi di EU termasuk memungkinkan perusahaan grup untuk melaporkan pajak konsolidasi dalam satu laporan. Dari laporan ini, pajak akan dikenakan sesuai dengan formula sehingga masing-masing negara dapat menegankan pajak atas penghasilan perusahaan tersebut 2 . CCCTB

\footnotetext{
${ }^{2}$ http://ec.europa.eu/taxation_customs/taxation/company_tax/common_tax_base/index_en.htm
} 
berfokus kepada seberapa besar penghasilan perusahaan yang seharusnya dikenakan pajak bukan pada seberapa besar tarif pajak ${ }^{3}$.

Bettendorf, Leon et al (2009) menyatakan bahwa CCCTB terdiri dari dua bagian yaitu Common Corporate Tax Base (CCTB) dan Consolidation With Formula (CFA). CCTB merupakan seperangkat peraturan yang mengatur mengenai peraturan umum tentang depresiasi fiskal, offset kerugian, dan insentif pajak. Sedangkan CFA merupakan formula yang digunakan perusahaan multinasional untuk menghitung tax base.

Kendala yang dihadapi dalam melalukan harmonisasi pajak langsung adalah terdapat beberapa negara anggota yang memiliki tarif yang lebih tinggi dibandingkan negara lain yang akan mengalami kerugian apabila harmonisasi diberlakukan4. Sistem perpajakan pada masing-masing negara anggota yang berbeda-beda merupakan kedaulatan dan kebijakan perpajakan masing-masing negara (Farrow \& Jogarajan,2006).

Sampai dengan saat ini, EU belum menerapkan harmonisasi pajak untuk pajak langsung. Dalam publikasinya di EU Direct Tax News Issue 43 May/Jun 2011, dinyatakan bahwa "the outlook for a truly harmonized and consolidated tax base appears rather gloomy"5. Tabel II.1 merupakan perkembangan harmonisasi pajak EU.

Dalam hal withholding tax, Komisi Eropa telah mengadopsi usulan Dewan berupa paket tiga langkah untuk mengatasi persaingan pajak berbahaya (harmful tax competition). Komisi mengusulkan ketiga paket tersebut pada bulan Oktober 1997 dan Dewan telah melanjutkan diskusi sejak saat itu atas berdasarkan kesepakatan pada Desember 1997. Paket pajak terdiri dari Petunjuk Dewan untuk memastikan tarif pajak efektif dari pendapatan bunga dari investasi lintas negara berupa tabungan, yang dibayarkan kepada individu dalam Uni Eropa kemudian dibuatnya Kode Etik untuk perpajakan atas usaha, serta untuk menghilangkan pemotongan pajak atas pembayaran bunga dan royalti yang dibayar antara perusahaan yang saling berhubungan di negara-negara anggota yang berbeda. Negara-negara anggota sepakat pada tahun 1997 bahwa paket ini diperlukan untuk membantu mencapai tujuan-tujuan tertentu seperti mengurangi distorsi berlanjut di pasar internal, mencegah kerugian yang berlebihan dari pengenaan pajak yang berlebihan dan restrukturisasi sistem pajak ke arah yang mendukung ketenagakerjaan.

\footnotetext{
3 http://www.tax-news.com/news/EU_Tax_Harmonization_Back_On_Agenda__45285.html

${ }^{4}$ Chetcuti (2001) http://www.chetcuticauchi.com/jpc/research/eu-tax-harmonization-4.htm

${ }^{5}$ http://www.ey.com/Publication/vwLUAssets/EU tax_news_May June 2011/\$FILE/EU\%20Direct $\% 2$ OTax\%20Newsletter\%20May-June \%202011.pdf
} 
Tabel 2.1.

Perkembangan Harmonisasi Pajak Uni Eropa

\begin{tabular}{|c|c|}
\hline Tahun & $\begin{array}{rr}\text { Deskripsi } \\
\end{array}$ \\
\hline 1962 & $\begin{array}{l}\text { Fritz Neumark mengajukan proposal untuk melakukan harmonisasi pajak secara } \\
\text { bertahap. Dimulai dari turnover taxes dan diperluas ke direct taxes dengan sistem } \\
\text { tarif vang dipisah (split rate). Proposal ini tidak ditindaklanjuti. }\end{array}$ \\
\hline 1970 & $\begin{array}{l}\text { Komite yang diketuai Prof Van Den Tempel merekomendasikan adopsi sistem } \\
\text { klasik. Usulan Prof Van den Termpel ditindaklanjuti oleh Dewan dengan } \\
\text { menyatakan pentingnya harmonisasi fiskal pada tahun } 1971 \text { dan } 1972 \text {. }\end{array}$ \\
\hline 1975 & $\begin{array}{l}\text { European Commission mengajukan proposal untuk mengharmonisasikan tarif } \\
\text { pajak sebesar } 45 \%-55 \% \text {. Namun usul ini dipertanyakan oleh European } \\
\text { Parlianment pada tahun 1979, karena agenda parlemen adalah untuk } \\
\text { mengharmonisasikan basis pajak. Propasal ini kemudian dibatalkan pada tahun } \\
1990 \text {. }\end{array}$ \\
\hline 1988 & $\begin{array}{l}\text { Rencana untuk mengharmonisasikan basis pajak diajukan oleh European } \\
\text { Commission, namun rencana tersebut tidak pernah dikirimkan ke Dewan. }\end{array}$ \\
\hline 1989 & Harmonisasi pajak di Eropa mulai melambat \\
\hline 1992 & $\begin{array}{l}\text { Komite memutuskan untuk mengkaji adanya perbedaan pajak mempengaruhi } \\
\text { keputusan investasi. Komite juga mengusulkan standar minimum untuk basis } \\
\text { pajak dan tarif pajak sebesar } 30-40 \% \text {. Namun proposal ini tidak ditindaklanjuti. }\end{array}$ \\
\hline 2001 & $\begin{array}{l}\text { European Commission menerbitkan laporan tentang tarif efektif pajak di EU } 15 \text { dan } \\
\text { kendala-kendala terkait pajak dalam Single Market. } \\
\text { European Commission juga mengusulkan sebagai berikut: } \\
\text { i. Harmonisasi penuh tarif dan basis pajak (EU Corporate Tax Rate) } \\
\text { ii. Basis Pajak dihitung dengan kewajiban untuk menerapkan metode yang } \\
\text { iii. Metode harmonisasi yang sama untuk menghitung basis pajak tapi bersifat } \\
\text { iv. Sistem Home State Taxation (perusahaan anak dikenakan pajak } \\
\text { berdasarkan peraturan perusahaan induk) }\end{array}$ \\
\hline
\end{tabular}

Sumber: Nicodeme, Gaetan.2006. Corporate Tax Competition and Coordination in the European Union: What do we know? Where do we stand? (http://mpra.ub.unimuenchen.de/107/ diakses pada tanggal 4 Juli 2011)

\section{HASIL DAN PEMBAHASAN}

\subsection{Kebijakan Perpajakan di ASEAN}

\subsubsection{Tarif Pajak Tidak Langsung}

Dari sisi tarif pajak yang dikenakan, perbandingan tarif pajak untuk pajak tidak langsung antar negara ASEAN dapat dilihat di tabel berikut: 
Tabel 3.1.

Tarif Pajak Tidak Langsung Negara ASEAN

\begin{tabular}{|l|c|c|c|c|c|c|c|l|}
\hline \multicolumn{1}{|c|}{ Country } & 2004 & 2005 & 2006 & 2007 & 2008 & 2009 & 2010 & Type ** \\
\hline Indonesia & 10 & 10 & 10 & 10 & 10 & 10 & 10 & VAT \\
\hline Malaysia & 10 & 10 & 10 & 10 & 10 & 10 & $4{ }^{*}$ & VAT/GST \\
\hline Philippines & 10 & 10 & 10 & 12 & 12 & 12 & 12 & VAT \\
\hline Thailand & 7 & 7 & 7 & 7 & 7 & 7 & 7 & VAT \\
\hline Vietnam & 10 & 10 & 10 & 10 & 10 & 10 & 10 & VAT \\
\hline Myanmar & $5-225$ & $5-225$ & $5-225$ & $5-225$ & $5-225$ & $5-225$ & $5-200$ & Commercial Tax \\
\hline Kamboja & & & & & & & 10 & VAT \\
\hline Laos & & & & & & & 10 & VAT \\
\hline Brunei & & & & & & & Nol Applicable & None \\
\hline Singapore & 5 & 5 & 5 & 5 & 7 & 7 & 7 & GST \\
\hline
\end{tabular}

Sumber : KPMG Corporate and Indirect Tax Rate Survey (2007\& 2010) dan Berlianto (2009)

*) Malaysia melakukan peralihan dari VAT menjadi GST terhitung sejak Maret/April 20106

**) Tidak semua negara ASEAN menggunakan nama yang sama untuk Pajak Tidak Langsung. Selain VAT (Value Added Tax) juga dikenal GST (Goods and Services Tax), atau Commercial Tax

Berdasarkan data pada tabel 3.1, terlihat bahwa tarif pajak tidak langsung dari negara ASEAN pada tahun 2004-2009 berada pada kisaran yang sama kecuali untuk Singapura yang menerapkan Goods and Services Tax dan Thailand yang tarif VAT-nya relatif lebih rendah serta Myanmar yang tarif Commercial Tax nya berada pada range yang cukup besar. Hampir semua negara ASEAN juga telah menerapkan VAT yang menunjukkan telah terjadinya konvergensi dalam penerapan pajak tidak langsung.

\subsubsection{Tarif Pajak Langsung}

Sedangkan perbandingan tarif pajak untuk pajak langsung antar negara ASEAN dapat dilihat di tabel 3.2 .

Sesuai data pada tabel 3.2, hampir seluruh negara ASEAN berusaha menurunkan tarif PPh Badannya kecuali Filipina, Thailand dan Laos yang cenderung mempertahankan tarif pajak yang lebih tinggi dibandingkan negaranegara anggota ASEAN lainnya. Indonesia pun melakukan hal yang sama dengan secara bertahap menurunkan tarif PPh Badan dari 30\% untuk tahun pajak 2008 menjadi 28\% untuk tahun pajak 2009 dan 25\% untuk tahun pajak 2010 dalam rangka menjaga tingkat kompetitif Indonesia dibandingkan negara lain di kawasan ASEAN. Posisi tarif PPh Badan Singapore cenderung lebih rendah dibanding negara ASEAN lainnya

\footnotetext{
${ }^{6}$ http://www.taxand.com/news/newsletters/Goods_Services_Tax_GST_Changes_for_Malaysia
} 
Tabel 3.2.

Tarif Pajak Penghasilan Badan Negara ASEAN

\begin{tabular}{|l|r|r|r|r|r|r|r|r|r|r|r|r|}
\hline \multicolumn{1}{|c|}{ Country } & 1999 & 2000 & \multicolumn{1}{c|}{2001} & 2002 & 2003 & 2004 & 2005 & 2006 & 2007 & 2008 & 2009 & 2010 \\
\hline Indonesia & 30 & 30 & 30 & 39 & 30 & 30 & 30 & 30 & 30 & 30 & 28 & 25 \\
\hline Malaysia & 28 & 28 & 28 & 28 & 25 & 28 & 28 & 28 & 27 & 26 & 25 & 25 \\
\hline Philippines & 33 & 32 & 32 & 32 & 32 & 32 & 32 & 35 & 35 & 35 & 30 & 35 \\
\hline Thailand & 30 & 30 & 30 & 30 & 30 & 30 & 30 & 30 & 30 & 30 & 30 & 30 \\
\hline Vieinam & 35 & 325 & 32 & 32 & 32 & 28 & 28 & 28 & 28 & 28 & 25 & 25 \\
\hline Myanmar & & & & & & 30 & 30 & 30 & 20 & 20 & 20 & 20 \\
\hline Kamboja & & & & & & 20 & 20 & 20 & 20 & 20 & 20 & 20 \\
\hline Laos & & & & & & NA & NA & NA & 35 & 35 & 35 & 35 \\
\hline Brunei & & & & & & 30 & 30 & 30 & 30 & 28 & 28 & 235 \\
\hline Singapore & 26 & 26 & 255 & 245 & 22 & 22 & 20 & 20 & 20 & 18 & 18 & 17 \\
\hline
\end{tabular}

Sumber: KPMG Corporate and Indirect Tax Survey (2007 \& 2010) dan Berlianto (2009)

\subsection{Keselarasan Kebijakan Perpajakan ASEAN}

\subsubsection{Persetujuan Penghindaran Pajak Berganda}

Terkait dengan tujuan ASEAN Tax Forum dimana salah satunya adalah menghindari terjadinya pajak berganda, Tax Treaty atau Perjanjian Penghindaran Pajak Berganda (P3B) merupakan salah satu dokumen yang menunjukkan upaya untuk menghindari terjadinya pajak berganda antar negara yang mengadakan perjanjian. Sampai dengan 2011 Indonesia telah mengadakan persetujuan P3B dengan lebih dari 58 negara. Sementara dengan negara ASEAN Indonesia telah mengadakan P3B dengan 6 negara ASEAN lainnya yang berlaku efektif. Negaranegara tersebut adalah:

Tabel 3.3.

Daftar Tax Treaty Indonesia dengan Negara ASEAN

\begin{tabular}{|l|l|l|l|}
\hline No & Negara & Saat Penandatanganan & $\begin{array}{l}\text { Saat Berlaku } \\
\text { Efektif }\end{array}$ \\
\hline 1 & Brunei Darussalam & 27 Februari 2000 & 1 Januari 2003 \\
\hline 2 & Malaysia & 12 September 1991 & 1 Januari 1987 \\
\hline 3 & Philippines & 18 Juni 1981 & 1 Januari 1983 \\
\hline 4 & Singapore & 8 Mei 1990 & 1 Januari 1992 \\
\hline 5 & Thailand & 21 Juli 2003 & 1 Januari 2004 \\
\hline 6 & Vietnam & 22 Desember 1997 & 1 Januari 2000 \\
\hline
\end{tabular}

Sumber: Direktorat Jenderal Pajak 
Dengan demikian masih ada 3 negara ASEAN lainnya yang belum terdapat Tax Treaty dengan Indonesia yaitu Myanmar, Laos dan Kamboja. Akan halnya dengan Myanmar, P3B sudah ditandangani namun belum efektif dijalankan. Sementara untuk di antara seluruh negara ASEAN lainnya, belum ada yang memiliki Tax Treaty dengan seluruh negara anggota ASEAN.

Tabel 3.4

Daftar Tax Treaty Antar Negara ASEAN

\begin{tabular}{|c|c|c|c|c|c|c|c|c|c|c|}
\hline & Brun & Cam & Indo & LPDR & Mal & Myan & Phil & Sing & Thai & Viet \\
\hline Brun & & & 2003 & & & & & 2007 & & \\
\hline \multicolumn{11}{|c|}{ Camb } \\
\hline Indo & 2003 & & & & 1986 & NEE & 1995 & 1992 & 2004 & 2000 \\
\hline LPDR & & & & & & & & & 1998 & N/E \\
\hline Mal & & & 1986 & & & ME & 1984 & 2007 & 1983 & 1997 \\
\hline Myan & & & NE & & $N / E$ & & & 2001 & $N / E$ & \\
\hline Phil & & & 1995 & & 1984 & & & 1977 & 1983 & 2004 \\
\hline Sing & 2007 & & 1992 & & 2007 & 2001 & 1977 & & 1976 & 1993 \\
\hline Thai & & & 2004 & 1998 & 1983 & NE & 1983 & 1976 & & 1993 \\
\hline Viet & & & 2000 & $N E$ & 1997 & & 2004 & 1993 & 1993 & \\
\hline
\end{tabular}

Sumber: KPMG Australia . 2006. ASEAN Tax Regimes and the Integration of the Priority Sectors: Issues and Options.

Dari tabel 3.4 terlihat bahwa Kamboja merupakan negara yang tidak memiliki Tax Treaty dengan negara ASEAN lainnya. Laos dan Myanmar juga memiliki Tax Treaty dengan negara ASEAN yang jauh lebih sedikit dibanding negara ASEAN lainnya.

Bila dilihat dari volume perdagangan antar negara ASEAN maupun dengan negara di luar ASEAN maka dapat dilihat pada tabel 3.5. 
Tabel 3.5.

Intra- and Extra-ASEAN Trade, 2009

(dalam juta US\$ dan \%)

\begin{tabular}{|c|c|c|c|c|c|}
\hline \multirow[b]{2}{*}{ Country } & \multicolumn{2}{|c|}{ Intra-ASEAN Irade } & \multicolumn{2}{|c|}{ Exire-ASEAN trade } & \multirow[b]{2}{*}{ Total Irade } \\
\hline & Value & $\begin{array}{l}\text { Share to } \\
\text { tolai trade }\end{array}$ & Value & $\begin{array}{l}\text { Shate to } \\
\text { iotal trade }\end{array}$ & \\
\hline Brine Danissalam & $2,472.1$ & 258 & 7090.1 & 742 & 9509.2 \\
\hline Cambodia & 2,0979 & 23.6 & $6,788.8$ & 764 & 8,8867 \\
\hline Ir.:nesa & $52,366.3$ & 245 & $160,972.9$ & 755 & 2133392 \\
\hline Lao PDR & $2,478.2$ & 83.7 & 484.0 & 16.3 & 2962.1 \\
\hline Ia aysa & $72,065.3$ & 257 & $208,155.0$ & 743 & 2802214 \\
\hline Inyanmar & 5262.4 & 51.6 & 4928.9 & 484 & $10,191,3$ \\
\hline The Prtipfines & $17,399.5$ & 20.7 & $60 \hat{4} 469.1$ & 793 & 838.36 \\
\hline Sngapo!e & 140.594 .1 & 27.3 & 371923.1 & 127 & $515,617.1$ \\
\hline Traiand & $59,250.1$ & 207 & 227.016 .7 & 793 & 280200.8 \\
\hline Viet Nam & $22,121.5$ & 17.6 & $103,800.4$ & 824 & $125,921.9$ \\
\hline ASEAN & $376,207.3$ & 24.5 & $1,160,635.9$ & 75.5 & $1,536,843.3$ \\
\hline
\end{tabular}

Sumber: http://www.ASEAN.org

Berdasarkan tabel nilai perdagangan ASEAN tersebut, Laos dan Myanmar yang belum memiliki banyak Tax Treaty dengan negara ASEAN lainnya justru porsi perdagangan terbesarnya adalah dengan sesama negara ASEAN.

Dikaitkan dengan teori tax harmonization kebijakan Tax Treaty merupakan bagian dari langkah cooperation yaitu melakukan perjanjian yang bersifat timbal balik demi kepentingan dua negara yang melakukan perjanjian. Melihat tabel Tax Treaty antar negara ASEAN menunjukkan bahwa terdapat negara-negara anggota ASEAN yang kurang aktif dalam melakukan perjanjian ini

\subsubsection{Rasio Penerimaan Pajak Terhadap PDB}

Langkah cooperation dalam teori tax harmonization merupakan langkah yang lebih maju dibanding langkah lainnya yaitu konvergensi, namun dalam menilai tax harmonization kiranya tidak dapat hanya dilihat dari adanya aturan penghindaran pajak berganda tersebut, Penyelarasan aturan perpajakan seyogyanya dilakukan juga terhadap tarif pajak dan tax base dari berbagai jenis pajak. Hal ini dimaksudkan untuk menghindari terjadinya tax competition di antara sesama negara ASEAN yang pada akhirnya akan merugikan komunitas ASEAN sendiri. 
Bila dilihat dari besaran persentase penerimaan pajak terhadap PDB, maka perbandingan penerimaan pajak terhadap PDB di antara negara anggota ASEAN adalah sebagai berikut:

Tabel 3.6.

Rasio Penerimaan Pajak terhada PDB dari Negara Anggota ASEAN Periode 1996-2009

\begin{tabular}{|l|r|r|r|r|r|r|r|r|r|r|r|r|r|r|}
\hline \multicolumn{1}{|c|}{ Country } & \multicolumn{1}{c|}{1996} & 1997 & 1998 & 1999 & 2000 & 2001 & 2002 & 2003 & 2004 & 2005 & 2006 & 2007 & 2008 & 2009 \\
\hline Indonesia & 9.74 & 10.23 & 9.7 & 10.36 & 8.34 & 11.27 & 11.53 & 12.02 & 12.22 & 12.46 & 12.26 & 12 & 13 & 11 \\
\hline Malaysia & 18.63 & 19.03 & 16.01 & 15.08 & 13.74 & 18.39 & 18.47 & 16.42 & 16.01 & 16.27 & 15.86 & 15 & 15 & 16 \\
\hline Singapore & 17.78 & 16.17 & 15.63 & 16.16 & 16.03 & 15.78 & 13.64 & 13.36 & 13.11 & 12.97 & 13.68 & 13 & 14 & 14 \\
\hline Thailand & 17.8 & 17.1 & 15.3 & 14.4 & 14.5 & 14.9 & 15.5 & 16.9 & 17.4 & 18.1 & 18.5 & 16 & 16 & 15 \\
\hline Phillipines & 16.94 & 16.99 & 15.63 & 14.5 & 13.71 & 13.59 & 12.81 & 12.75 & 12.41 & 12.96 & 14.25 & 14 & 14 & 13 \\
\hline Bunei & 18.9 & 20.46 & 23.19 & $N .9$ & 32.55 & 30.82 & 30.48 & 31.5 & 39.56 & 33.11 & 30.02 & N.a & N.a & N.a \\
\hline Vieinam & 18.49 & 15.85 & 15.43 & 15.08 & 14.51 & 15.77 & 16.84 & 19.32 & 19.32 & 19.8 & 21.6 & N.a & N.a & N.a \\
\hline Myanmar & 3.65 & 4.1 & 3.29 & 2.4 & 2.65 & 2.02 & 1.86 & 2.1 & 2.92 & 3.65 & 4.05 & N.a & N.a & N.a \\
\hline Lao PDR & 11.01 & 13.18 & 17.57 & 13.24 & 11.92 & 11.94 & 10.48 & 10.34 & 10.56 & 11.86 & 11.82 & 11 & 12 & 13 \\
\hline Cambodia & 5.8 & 5.9 & 5.8 & 7.1 & 7.3 & 7.2 & 7.4 & 6.6 & 7.7 & 7.6 & 7.9 & 10 & 11 & 10 \\
\hline
\end{tabular}

Sumber: CEIC

Persentase penerimaan pajak terhadap PDB dari negara-negara ASEAN umumnya berada pada kisaran 10-16\% kecuali untuk Myanmar yang masih sangat rendah yaitu di bawah $5 \%$ dan Brunei Darussalam yang sangat tinggi mencapai $30 \%$. Persentase ini dapat diartikan ke beberapa hal yaitu:

1. Negara anggota ASEAN yang persentase penerimaan pajak terhadap PDB nya relatif lebih rendah dibandingkan negara lain akan berusaha meningkatkan penerimaan pajaknya baik dengan meningkatkan tarif pajak maupun memperluas basis pajak,

2. Negara anggota ASEAN yang persentase penerimaan pajak terhadap PDB nya relatif lebih tinggi dibandingkan negara lain akan berusaha meningkatkan iklim investasi dengan penurunan tarif maupun menambah tax exemption.

\subsection{Pembelajaran Dari Harmonisasi Perpajakan Uni Eropa}

Mengacu pada pengalaman Uni Eropa dalam melakukan harmonisasi perpajakan, dibutuhkan waktu berpuluh tahun untuk menyelaraskan perpajakan di antara negara Uni Eropa, bahkan sampai saat ini pun masih terus berproses. Pembahasan yang dilakukan pada bagian ini adalah dengan membandingkan tarif pajak antara kedua kawasan kemudian proses yang dapat dilakukanASEAN.

Tarif pajak tidak langsung ASEAN telah dijelaskan pada bagian 3.1, sedangkan tarif pajak tidak langsung di Uni Eropa sesuai dengan tabel 3.7 di bawah ini. 
Tabel 3.7

Tarif Pajak Tidak Langsung Negara Uni Eropa 2004-2009

\begin{tabular}{|l|l|r|r|r|r|r|r|}
\hline & & \multicolumn{3}{|c|}{ Indirect Tax (VAT) } \\
\hline No & Country & 1-Jan-04 & 1-Jan-05 & 1-Jan-06 & 1-Jan-07 & 1-Apr-08 & 1-Jan-09 \\
\hline 1 & Austria & 20 & 20 & 20 & 20 & 20 & 20 \\
\hline 2 & Belgium & 21 & 21 & 21 & 21 & 21 & 21 \\
\hline 3 & Bulgaria & 20 & 20 & 20 & 20 & 20 & 20 \\
\hline 4 & Cyprus & 15 & 15 & 15 & 15 & 15 & 15 \\
\hline 5 & Czech Republic & 22 & 19 & 19 & 19 & 19 & 19 \\
\hline 6 & Denmark & 25 & 25 & 25 & 25 & 25 & 25 \\
\hline 7 & Estonia & 18 & 18 & 18 & 18 & 18 & 20 \\
\hline 8 & Finland & 22 & 22 & 22 & 22 & 22 & 22 \\
\hline 9 & France & 19.6 & 19.6 & 19.6 & 19.6 & 19.6 & 19.6 \\
\hline 10 & Germany & 16 & 16 & 16 & 19 & 19 & 19 \\
\hline 11 & Greece & 18 & 18 & 19 & 19 & 19 & 19 \\
\hline 12 & Hungary & 25 & 25 & 20 & 20 & 20 & 25 \\
\hline 13 & Ireland & 21 & 21 & 21 & 21 & 21 & 215 \\
\hline 14 & Italy & 20 & 20 & 20 & 20 & 20 & 20 \\
\hline 15 & Latvia & 18 & 18 & 18 & 18 & 18 & 21 \\
\hline 16 & Lithuania & 18 & 18 & 18 & 18 & 18 & 19 \\
\hline 17 & Luxembourg & 15 & 15 & 15 & 15 & 15 & 15 \\
\hline 18 & Malta & 18 & 18 & 18 & 18 & 18 & 18 \\
\hline 19 & Netherlands & 19 & 19 & 19 & 19 & 19 & 19 \\
\hline 20 & Poland & 22 & 22 & 22 & 22 & 22 & 22 \\
\hline 21 & Portugal & 19 & 19 & 21 & 21 & 21 & 20 \\
\hline 22 & Romania & 19 & 19 & 19 & 19 & 19 & 19 \\
\hline 23 & Slovakia & $\# \mathrm{~N} / \mathrm{A}$ & $\# \mathrm{~N} / \mathrm{A}$ & $\# \mathrm{~N} / \mathrm{A}$ & $\# \mathrm{~N} / \mathrm{A}$ & $\# \mathrm{~N} / \mathrm{A}$ & $\# \mathrm{~N} / \mathrm{A}$ \\
\hline 24 & Slovenia & 20 & 20 & 20 & 20 & 20 & 20 \\
\hline 25 & Spain & 16 & 16 & 16 & 16 & 16 & 16 \\
\hline 26 & Sweden & 25 & 25 & 25 & 25 & 25 & 25 \\
\hline 27 & United Kingdom & 175 & 175 & 175 & 17.5 & 175 & 15 \\
\hline
\end{tabular}

Sumber: CEIC

Tarif pajak tidak langsung negara Uni Eropa cukup beragam sebagaimana tergambar pada tabel di atas, dari yang terendah 15\% sampai yang tertinggi mencapai $25 \%$. Tarif pajak negara-negara tersebut pun tidak menggambarkan konvergensi menuju ke satu tarif yang hampir sama sampai dengan tahun 2009.

Seperti telah dijelaskan sebelumnya tarif pajak tidak langsung negara ASEAN umumnya berkisar antara 7-12\%. Bila dibandingkan dengan tarif pajak tidak langsung negara Uni Eropa yang berkisar antara 15-25\% maka tarif negara ASEAN relatif lebih rendah dibanding negara Uni Eropa. Selain itu range perbedaan tarif pajak tidak langsung di negara ASEAN cenderung lebih sempit yaitu sekitar $5 \%$ dibandingkan dengan range negara-negara Uni Eropa yang mencapai 10\%. Pada dasarnya, melihat range perbedaan yang lebih kecil, seharusnya lebih mudah untuk 
menyelaraskan tarif pajak tidak langsung di kawasan ASEAN, namun perlu dipertimbangkan juga strategi dan kedaulatan masing-masing negara ASEAN sehingga memilih tarif seperti yang ada saat ini.

Tabel 3.8.

Tarif Pajak Langsung Negara Uni Eropa 1999-2009

\begin{tabular}{|c|c|c|c|c|c|c|c|c|c|c|c|c|}
\hline No & Country & 1-Jan-99 & 1-Jan-00 & 1.Jan-01 & 1-Jan-02 & 1-Jan-03 & 1-Jan-04 & 1-Jan-05 & 1-Jan-06 & 1-Jan-07 & 1.Jan-08 & 1-Jan-09 \\
\hline 1 & Austria & 34 & 34 & 34 & 34 & 34 & 34 & 25 & 25 & 25 & 25 & 25 \\
\hline 2 & Belgium & 40.17 & 40.17 & 40.17 & 40.17 & 33.99 & 33.99 & 33.99 & 33.99 & 33.99 & 33.99 & 33.99 \\
\hline 3 & Bulgaria & 0 & 0 & 0 & 0 & 0 & 0 & 15 & 15 & 10 & 10 & 10 \\
\hline 4 & Cyprus & 0 & 0 & 28 & 28 & 15 & 15 & 10 & 10 & 10 & 10 & 10 \\
\hline 5 & Czech Republic & 35 & 31 & 31 & 31 & 31 & 28 & 26 & 24 & 24 & 21 & 20 \\
\hline 6 & Denmark & 32 & 32 & 30 & 30 & 30 & 30 & 28 & 28 & 28 & 25 & 25 \\
\hline 7 & Estonia & 0 & 0 & 0 & 0 & 0 & 0 & 24 & 23 & 22 & 21 & 21 \\
\hline 8 & Finland & 28 & 29 & 29 & 29 & 29 & 29 & 26 & 26 & 26 & 26 & 26 \\
\hline 9 & France & 40 & 36.66 & 35.33 & 34.33 & 34.33 & 34.33 & 33.83 & 33.33 & 33.33 & 33.33 & 33.33 \\
\hline 10 & Germany & 52.3 & 51.6 & 38.36 & 38.36 & 39.58 & 38.29 & 38.31 & 38.34 & 38.36 & 29.51 & 29.44 \\
\hline 11 & Greece & 40 & 40 & 37.5 & 35 & 35 & 35 & 32 & 29 & 25 & 25 & 25 \\
\hline 12 & Hungary & 18 & 18 & 18 & 18 & 18 & 16 & 16 & 16 & 16 & 16 & 16 \\
\hline 13 & Ireland & 28 & 24 & 20 & 16 & 12.5 & 12.5 & 12.5 & 12.5 & 12.5 & 12.5 & 12.5 \\
\hline 14 & Italy & 41.25 & 41.25 & 40.25 & 40.25 & 38.25 & 37.25 & 37.25 & 37.25 & 37.25 & 31.4 & 31.4 \\
\hline 15 & Lalvia & 25 & 25 & 25 & 22 & 19 & 15 & 15 & 15 & 15 & 15 & 15 \\
\hline 16 & Lithuania & 0 & 0 & 0 & 0 & 0 & 0 & 15 & 15 & 15 & 15 & 20 \\
\hline 17 & Luxembourg & 37.45 & 37.45 & 37.45 & 30.38 & 30.38 & 30.38 & 30.38 & 29.63 & 29.63 & 29.63 & 28.59 \\
\hline 18 & Malta & 0 & 0 & o & 0 & 34 & 0 & 35 & 35 & 35 & 35 & 35 \\
\hline 19 & Netherlands & 35 & 35 & 35 & 34.5 & 34.5 & 34.5 & 31.5 & 29.6 & 25.5 & 25.5 & 25.5 \\
\hline 20 & Poland & 34 & 30 & 28 & 28 & 27 & 19 & 19 & 19 & 19 & 19 & 19 \\
\hline 21 & Portugal & 37.4 & 37.4 & 35.2 & 33 & 33 & 27.5 & 27.5 & 27.5 & 25 & 25 & 25 \\
\hline 22 & Romania & 0 & 0 & 25 & 25 & 25 & 25 & 46 & 16 & 16 & 16 & 16 \\
\hline 23 & Slovakia & $\# N / A$ & \#N/A & \#NIA & \#N/A & \#N/A & $\# N / A$ & $\# N / A$ & $\# N / A$ & \#N/A & \#N/A & $\# N / A$ \\
\hline 24 & Slovenia & 25 & 25 & 25 & 25 & 25 & 25 & 25 & 25 & 23 & 22 & 21 \\
\hline 25 & Spain & 35 & 35 & 35 & 35 & 35 & 35 & 35 & 35 & 32.5 & 30 & 30 \\
\hline 26 & Sweden & 28 & 28 & 28 & 28 & 28 & 28 & 28 & 28 & 28 & 28 & 26.3 \\
\hline 27 & United Kingdom & 31 & 30 & 30 & 30 & 301 & 30 & 30 & 30 & 30 & 28 & 28 \\
\hline
\end{tabular}

Sumber: CEIC

Tarif PPh Badan negara Uni Eropa pada tahun 2009 berkisar antara 10\% di negara Bulgaria dan Cyprus sampai dengan 33,99\% di Belgia. Seperti juga pada Pajak tidak langsung, tarif PPh Badan negara-negara Uni Eropa tidak menunjukan mengarah kepada satu tarif yang hampir sama. Range tarif PPh Badan negara Uni Eropa yaitu 10-33,99\% jauh lebih besar dibanding negara ASEAN yang berkisar antara $17-35 \%$. Seperti juga negara ASEAN, sebagian besar negara Uni Eropa menunjukkan kecenderungan menurunkan tarif PPh Badan. Inggris misalnya, dari $31 \%$ di tahun 1999 menjadi $30 \%$ di tahun 2000 dan turun kembali menjadi $28 \%$ di tahun 2008.

Keragaman tarif pajak negara Uni Eropa menunjukan bahwa kebijakan tarif pajak tidak dapat diseragamkan begitu saja. Setiap negara walaupun telah tergabung dalam suatu komunitas secara resmi tetap memiliki kedaulatan untuk 
Kajian Ekonomi dan Keuangan, Volume 15 No. 1 Tahun 2011

menentukan tarif pajaknya sesuai dengan strategi dan kebijakan fiskal di negara masing-masing.

Belajar dari pengalaman Uni Eropa dalam hal harmonisasi tarif pajak, walaupun range tarif pajak ASEAN relative lebih kecil dibanding negara-negara Uni Eropa, namun bukan berarti tarif kedepannya dipaksakan harus sama. Sehingga penyamaan tarif pajak bukan menjadi tujuan utama dalam tax harmonization, melainkan untuk menemukan dasar pengenaan pajak yang seragam (tax base).

\subsection{Menuju Kawasan ASEAN yang Lebih Kompetitif Dengan Harmonisasi Perpajakan}

Sebagaimana diuraikan pada bagian II, Uni Eropa telah melakukan tahapan yang cukup panjang dalam harmonisasi perpajakan sejak tahun 1962 sampai dengan sekarang. Pada tahun 2009, EU mengusulkan Common Consolidated Corporate Tax Base (CCCTB). CCCTB berfokus kepada seberapa besar penghasilan perusahaan yang seharusnya dikenakan pajak bukan pada seberapa besar tarif pajaknya. Pajak yang diharmonisasikan juga masih hanya mencakup pajak langsung dan sampai dengan saat ini, EU belum menerapkan harmonisasi pajak untuk pajak tidak langsung.

Berdasarkan pengalaman Uni Eropa tersebut, menunjukkan bahwa mengharmonisasikan perpajakan terutama tarif pajak bukan perkara yang mudah. Dalam menentukan kebijakan pajak, masing-masing negara tentu mempunyai berbagai pertimbangan. Walaupun proses harmonisasi pajak Uni Eropa telah melalui berbagai tahapan, namun baru dalam proses mencapai kesepakatan untuk menyelaraskan pajak langsung, belum mencapai tahap standarisasi seperti yang digambarkan oleh Velayos (2007).

Sesuai proses yang terjadi di Uni Eropa, dalam melakukan harmonisasi perpajakan sebaiknya ASEAN tidak fokus kepada penyamaan tarif pajak melainkan lebih kepada penyelarasan basis pajak. Hal ini mengingat bahwa masing-masing negara memiliki kebijakan fiskal tersendiri dalam menetapkan tarif pajak yang diterapkan.

Tarif pajak langsung dan tidak langsung negara-negara anggota ASEAN yang relatif lebih rendah apabila dibandingkan dengan negara-negara anggota EU merupakan salah satu keunggulan kompetitif yang dimiliki. Tarif pajak merupakan salah satu pertimbangan investor dalam melakukan investasi. Sehingga dengan tarif pajak yang kompetitif akan mampu menarik investor kedalam kawasan ASEAN.

Pada akhirnya, berdirinya ASEAN Tax Forum merupakan langkah awal yang baik dalam penyelarasan sistem perpajakan di kawasan ASEAN. Diharapkan dengan ASEAN Tax Forum, anggota ASEAN akan semakin sadar untuk melakukan harmonisasi pajak minimal pada tingkat Cooperation melalui Persetujuan Penghindaran Pajak Berganda antar negara ASEAN. Belum semua negara anggota 
ASEAN memiliki P3B satu sama lain memberikan gambaran bahwa tujuan cooperation untuk memberikan asistensi timbal balik dan saling menguntungkan belum disadari sepenuhnya. Langkah ke depan, diharapkan ASEAN Tax Forum mampu mendorong masing-masing negara anggota untuk mencapai tingkatan yang lebih tinggi dalam harmonisasi pajak.

\section{KESIMPULAN DAN SARAN}

\subsection{Kesimpulan}

1. ASEAN Tax Forum merupakan sarana untuk menjadikan kawasan ASEAN yang lebih kompetitif melalui penyelarasan sistem perpajakan di antara negara ASEAN. Penyelarasan pajak memerlukan beberapa tahap yang harus dilakukan dengan tahap yang mendasar berupa convergence.

2. Persetujuan Penghindaran Pajak Berganda sebagai salah satu langkah penyelarasan pajak telah dilakukan negara- negara Anggota ASEAN walaupun masih terdapat negara ASEAN yang belum sama sekali melakukan persetujuan tersebut yaitu negara Kamboja dan terdapat negara yang persetujuan Penghindaran Pajak Bergandanya dengan sesama negara anggota ASEAN sangat sedikit yaitu Myanmar dan Laos.

3. Dalam hal tarif pajak tidak langsung di antara negara anggota ASEAN, umumnya berada pada kisaran tarif pajak yang sama yaitu $10-12 \%$ kecuali Singapore yang menerapkan GST 7\% dan Malaysia yang berencana menerapkan GST sebesar 4\%. Sementara tarif pajak penghasilan terdapat kecenderungan tarif yang menurun di antara negara anggota ASEAN kecuali Filipina dan Laos. Sedangkan tarif PPh Badan Singapura relatif lebih rendah dibanding negara Anggota ASEAN lainnya.

4. Bila mengacu pada model tax harmonization yang dilakukan Uni Eropa (EU) maka yang dilakukan adalah menyelaraskan pajak tidak langsung berupa tarif standar PPN namun terdapat variasi untuk pajak tidak langsung terkait dengan produk beralkohol, BBM, dan tembakau. Sedangkan untuk pajak langsung penyelarasan yang dilakukan lebih ke menerapkan basis pajak yang sama, sedangkan tarif pajak tetap diserahkan ke negara masing-masing.

5. Pada dasarnya tarif pajak langsung maupun tidak langsung Negara Anggota ASEAN relatif lebih rendah dibandingkan dengan negara Uni Eropa. Sedangkan tarif PPh Badan baik negara ASEAN maupun Uni Eropa menunjukkan kecenderungan penurunan dari tahun ke tahun. Hal ini menunjukkan dalam hal tarif pajak, sebenarnya ASEAN dapat bersaing dengan Uni Eropa. 


\subsection{Saran}

1. Pada tingkat cooperation, ASEAN perlu memastikan bahwa Perjanjian Penghindaran Pajak Berganda antar seluruh negara ASEAN dapat diwujudkan dalam bentuk nyata dengan tujuan untuk memastikan terwujudnya kondisi non-double taxation, yang merupakan langkah awal untuk melakukan harmonisasi pajak.

2. Mengacu pada langkah yang telah dijalankan Uni Eropa maka penyelarasan pajak terutama pajak langsung di kawasan ASEAN sebaiknya tidak dengan serta merta menuju ke arah penyamaan jenis dan tarif pajak tetapi lebih ke penyelarasan basis pajak untuk mengarah kepada tax burden yang setara antar negara ASEAN. Penyelarasan basis pajak dapat dilakukan dengan mengacu kepada IFRS(International Financial Report Standard). . IFRS dapat memberikan starting point dalam hal pengakuan pendapatan, definisi aset dan hutang, dan pengukuran awal aset dan depresiasi (Wendt:2009,202).

3. Penelitian lebih lanjut diperlukan untuk mensimulasikan efektifitas kebijakan apabila dilakukan harmonisasi pajak baik tarif maupun tax base untuk jenis pajak langsung maupun tidak langsung. Simulasi tersebut dapat dilakukan antara lain dengan menggunakan metode Cortax (Bettendorf:2009) yang mengacu kepada OECDTAX-model Sørensen.

\section{Daftar Pustaka}

Berlianto, Aprinto.2009.Tax Competition and Harmonization in Southeast Asia. Massey University, Albany

Bettendorf, Leon; Michael P. Devereux: Albert van der Horst; Simon Loretz; \& Ruud A. de Mooij.2009. Corporate Tax Harmonization in the EU. Economic Policy Fiftieth Panel Meeting. Universiteit van Tilburg. 23-24 October 2009

Bond, Stephen; Lucy Chennells; Michael P. Devereux; Malcolm Gammie; \& Edward Troup. 2000. Corporate Tax Harmonisation in Europe:A Guide to the Debate. The Institute for Fiscal Studies

Dunkley, Graham. 2004.Free Trade:Myth, Reality, and Alternatives.Zedbooks. London

Edwards Chris R.\& Daniel Mitchell.2008. Global tax revolution: the rise of tax competition and the battle to defend it.Cato Institute.USA

Farrow, Ian \& Sunita Jogarajan. 2006. ASEAN Tax Regimes and the Integration of the Priority Sectors: Issues and Options. KPMG Australia

Hayes, Kristen E. 2007.Integration, tax competition and harmonization:Should ASEAN be concerned? Lund University.Department of Economic History

KPMG International.2007. KPMG's Corporate and Indirect Tax Rate Survey 2007 2009.KPMG's Corporate and Indirect Tax Rate Survey 2009 
2010. ASEAN +2 Indirect Taxation Country Overview 2010

Lessambo, Felix Dr. 2010.Fundamentals of European Union Direct Tax. Rosedog Books. Pittsburgh USA

Tohari, Achmad \& Anna Retnawati. 2010.Is There Tax Competition in ASEAN? Bulletin for International Taxation. IBFD

Wendt, Carsten.2009 A Common Tax Base for Multinational Enterprises in the European Union. Gabler. Germany

Chetcuti, Jean-Philippe $\mathrm{Dr}$. The Process of Corporate Tax Harmonisation in the EC.2001. (diakses di http://www.chetcuticauchi.com/ipc/research/eu-taxharmonization.htm

Deloitte.2007. Corporate Tax Rate 2007-2011

(www.deloitte.com/assets/.../Tax/dtt corporate tax rates 2007 2011.pdf diakses pada tanggal 1 Juli 2011)Nicodeme, Gaetan.2006. Corporate Tax Competition and Coordination in the European Union: What do we know? Where do we stand? (http://mpra.ub.uni-muenchen.de/107/ diakses pada tanggal 4 Juli 2011)

KPMG Australia.2006. ASEAN Tax Regimes and the Integration of the Priority Sectors: Issues and Options (http://www.ASEAN.org/aadcp/repsf/docs/05005-ExecutiveSummary.pdf diakses pada 1 Juli 2011)

Velayos, Fernando; Alberto Barreix; \& Luiz Villela. 2007. Regional Integration and Tax Harmonization: Issues and Recent Experiences (siteresources.worldbank.org/INTTPA/Resources/Velayos-VillelaBarreix.pdf diakses pada Juni 2011)

Winner, Hannes., 2005, Has Tax Competition Emerged in OECD Countries? Evidence from Panel Data International Tax and Public Finance, (http://goliath.ecnext.com/coms2/gi 0198-353471/Has-tax-competitionemerged-in.html diakses pada 1 Juli 2011) 


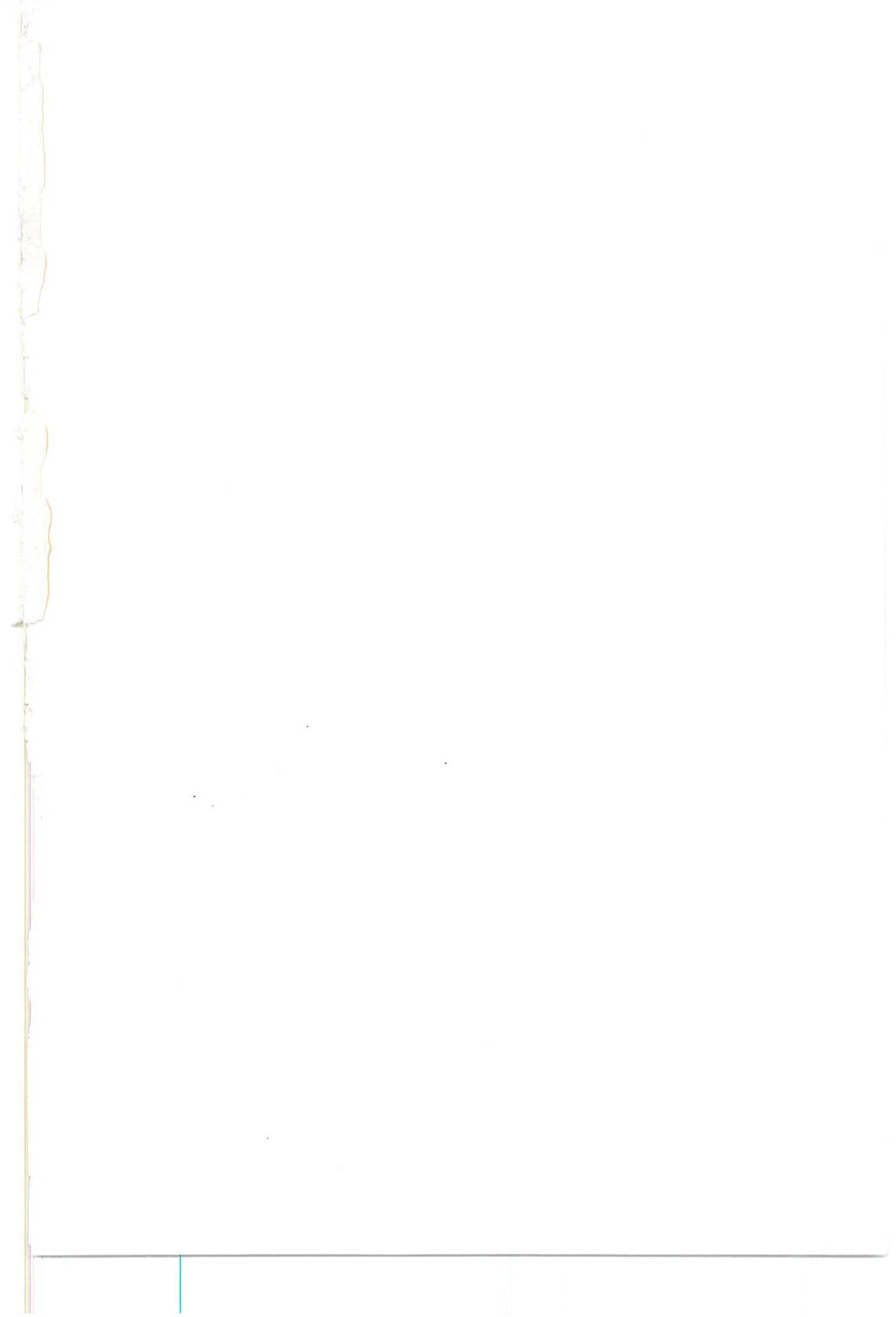

